\title{
Beta-thalassemia in Mediterranean countries. Findings and outlook
}

\author{
Beta-talasemia en los países mediterráneos. Adquisiciones y perspectivas
}

\author{
Gil Bellis ${ }^{1^{*}}$ (iD \\ Alain Parant ${ }^{2}$
}

\begin{abstract}
Beta-thalassemia is one of the most common genetic disorders among humans. It occurs in many world regions, but the highest levels are recorded in the Mediterranean countries. This study reviews the epidemiology of $\beta$-thalassemia in these countries, as well as their resources for fighting the disease, and establishes an outlook on the trends in the pathology between now and 2050. The epidemiological parameters are based on information from specialised databases, while the outlook is derived from the global population forecasts of the United Nations. With an incidence rate at birth of 15.9 cases per 100,000 newborns, the Northern coast of the Mediterranean is the least impacted and has significant health infrastructures; the number of newborns concerned could decrease by 2050 . The incidence rate on the Eastern Mediterranean coast, where numerous prevention programmes are available, is twice as high, at 31.4 per 100,000 newborns; over the next 30 years, the number of new cases at birth could increase. The incidence rate on the Southern Mediterranean coast is highest, at 36.8 per 100,000 newborns, and the region continues to suffer from a shortage of health infrastructures; the number of new cases at birth could increase considerably in the region between now and 2050. These long-term projections are based on population growth in the Mediterranean countries and will be changed only by the widespread use of antenatal practices against $\beta$-thalassemia. The findings of this study could enable the countries concerned to adapt their healthcare policies.
\end{abstract}

Keywords: Mediterranean countries; beta-thalassemia; incidence; prevalence; demographic outlook.

\section{Resumen}

La beta-talasemia es una de las enfermedades genéticas más comunes en el género humano; está presente en casi todo el mundo pero alcanza sus niveles más altos en los países mediterráneos. Los objetivos de este estudio son realizar un balance de la epidemiología de la enfermedad en dichos países, de los medios de control de que disponen, para luego realizar perspectivas de la evolución de esta patología de aquí al año 2050. Los parámetros epidemiológicos se construyeron a partir de información obtenida de bases de datos especializadas; las perspectivas se establecen a partir de las previsiones de la población mundial elaboradas por las Naciones Unidas. Con una tasa de incidencia al nacimiento de 15,9 casos por 100.000 recién nacidos, los países del norte del Mediterráneo son los menos afectados y disponen de infraestructuras sanitarias importantes; el número de recién nacidos enfermos podría disminuir para 2050. Los países del este del Mediterráneo están afectados casi dos veces más (31,4 por 100.000) pero cuentan con numerosos programas de prevención; en los próximos 30 años, el número de casos nuevos al nacer podría aumentar. Los países del sur son los más afectados (36,8 por 100.000) y siguen estando

1 Institut national d'études démographiques, France. bellis@ined.fr. * Corresponding author

2 Futuribles International, France. aparant@futuribles.com 
mal equipados en infraestructuras sanitarias; el número de nuevos casos al nacer podría aumentar significativamente hasta 2050. Estas perspectivas a largo plazo están ligadas al crecimiento demográfico de la cuenca mediterránea y sólo se verían modificadas por la generalización de las prácticas antinatales contra la $\beta$-talasemia. Los resultados de este estudio podrían permitir a los Estados implicados llevar a cabo las acciones de salud adecuadas.

Palabras clave: Países mediterráneos; beta-talasemia; incidencia; prevalencia; previsión demográfica.

\section{Introduction}

Thalassemias are genetic diseases characterized by a deficit in the production of hemoglobin, the protein contained in red blood cells that transports oxygen in the bloodstream. The disease is qualified as $\alpha$-thalassemia or $\beta$-thalassemia depending on whether the anomaly results from a defect in the synthesis of the alpha $(\alpha)$ chains or beta $(\beta)$ chains making up the protein. This study will focus solely on the latter, owing to its frequency and severity.

The synthesis of the $\beta$ chains of human hemoglobin is controlled by a gene located on chromosome 11 , mutations of which make it defective and non-functional (Cao and Galanello, 2010). The transmission of the gene corresponds to a recessive hereditary mode leading to one of three situations: the two chromosome 11 s of an individual's genome both contain a non-mutated gene, in which case the individual is not affected (healthy homozygous); one of the two chromosomes contains a mutated gene, in which case the individual is not ill but a carrier (healthy heterozygous); or both chromosomes contain a mutated gene, in which the individual has $\beta$-thalassemia (diseased homozygous).

$\beta$-thalassemia is one of the most common genetic disorders among humans. It mainly occurs in the Mediterranean countries but is also found in the Middle East, West Africa, India, and South-East Asia. The total number of individuals with $\beta$-thalassemia is unknown. This lack of knowledge can be attributed to the existence in some countries merely of patient registers and, above all, to early mortality occurring before the disease is diagnosed among children with the most severe cases, the number of children born with $\beta$-thalassemia every year having been estimated at 60,000 worldwide (Angastiniotis and Lobitz, 2019).

Symptoms vary among individuals. Those with major and intermediate forms of $\beta$-thalassemia suffer from severe anaemia (Cooley's anaemia), growth disorders and febrile illnesses occurring from the first year of life. To offset the lack of hemoglobin, bone-marrow activity is overstimulated, leading gradually to an enlargement of the liver (hepatomegaly) and the spleen (splenomegaly). If these symptoms go untreated, they generally result in death before the age of five (Galanello and Origa, 2010). Various treatments are available according to the patient's age and the severity of the disorder. These include regular blood transfusions in the most common cases; the removal of the spleen (splenectomy) where transfusion requirements become excessive; bone-marrow transplants, which have lasting therapeutic effects but require grafts by experienced medical specialists from a non-affected and compatible family member (Higgs, Engel and Stamatoyannopoulos, 2012; Weatherall and Clegg, 2001). Despite their efficacy, repeated blood transfusions lead to an excessive accumulation of iron, though this may be addressed through regular doses of iron chelators (Ceci, et al., 2006). Substantial resources are harnessed to treat $\beta$-thalassemia, a UK study having estimated that the cost of complete life-long treatment is between $€ 210,000$ and $€ 250,000$ (Karnon, et al., 1999).

The persistence of what is a lethal disease can be explained by two factors (De Sanctis, et al., 2017). The first is the positive selection of heterozygous individuals against malaria. The slight decrease in the globulin levels of these patients (microcytosis) lends them a certain degree of resistance against the destruction of red blood cells caused by the malaria parasite, plasmodium (Allison, 2009; Flint, Harding, Boyce and Clegg, 1998). It has been established that the clearing of forests and savanna starting in the Neolithic period for the purposes of agriculture and livestock farming created ecological conditions favourable to the proliferation of plasmodium. In response to this environmental pressure, natural selection retained the genetic variations ensuring reproductive advantages to certain individuals. This gradually led to today's situation, whereby in malaria-impacted areas heterozygous individuals survive but, in the event of union with another heterozygous individual, have a 25\% risk on each conception of giving birth to a diseased homozygous child. The second factor is the consanguinity corresponding to the reproduction in a population of couples in which both members share one or more common ancestors. These 
unions are based on cultural traditions and concern around 20\% of the world population, the highest consanguinity rates being observed in North Africa and the Middle East, where the proportion of consanguine marriages stands at 30\% to $40 \%$ in rural or disadvantaged areas (Bener and Mohammad, 2017; Bittles, Mason, Greene and Rao, 1991; Tadmouri, et al., 2009). Consanguinity doubles the risk of genetic anomalies, from $2 \%$ to $3 \%$ for non-related individuals to $4 \%$ to $5 \%$ for a couple of first cousins. The recessive hereditary mode alone is related to the increase in this risk. A genetic mutation that is rare among a population has a high probability of existing in two parents where they have one or more common ancestors, and the child of such a couple may be homozygous diseased as a result of inheriting two copies of the same ancestral mutation.

Given the prevalence and severity of $\beta$-thalassemia and the cost of treatment, the World Health Organization (WHO) recommends a prevention-based approach (WHO, 2005). Aimed at preventing the birth of diseased children, this strategy combines several methods (Godard, Kate, Evers-Kiebooms and Aymé, 2003), including genetic advice, to inform heterozygous couples of the risks for their offspring; prenatal diagnoses, to identify the genetic anomaly at the foetal stage and enable the voluntary termination of the pregnancy; and pre-implantation diagnoses, to detect the genetic anomaly in the embryonic stage and enable the elimination of the affected embryos. Prevention has proven effective in Mediterranean countries strongly impacted by the disorder and which have opted for the approach, among them Cyprus, Greece, and Italy (Cao, Rosatelli, Monni and Galanello, 2002).

Addressing the multiple aspects of $\beta$-thalassemia and the health and socio-economic difficulties involved for the countries concerned, this study focuses on one of the most affected geographical regions, the countries on the Mediterranean coast. Our aim is to review, on the basis of carrier prevalence, the incidence rates of the disorder in these countries and the medical resources at their disposal. We then draw on a comparative approach to establish a long-term outlook on the possible trends in the disease consistent with population growth in the Mediterranean Basin. The aim with our findings is to direct the attention of the health authorities to a number of public health challenges likely to be posed in the future.

\section{Methodology}

The countries included in the study have a Mediterranean coastline. They belong to three groups: the European coast (or Northern coast), comprising Spain, France, Italy, Malta, Slovenia, Croatia, Bosnia and Herzegovina, Montenegro, Albania, and Greece; the Asian coast (Eastern coast), composed of Turkey, Cyprus, Syria, Lebanon, Israel, and the State of Palestine; and the African coast (Southern coast), comprising Egypt, Libya, Tunisia, Algeria, and Morocco. Gibraltar and Monaco (Northern coast) and the autonomous Spanish cities of Ceuta and Melilla (Southern coast) have been excluded for reasons of statistical consistency.

For each country, the data on the epidemiology of $\beta$-thalassemia (prevalence and incidence), health services and monitoring tools (special medical centres, availability of blood transfusion and iron chelators, existence of patient registers) and prevention systems (existence of national or regional programmes) come from specialized databases: IthaGenes (Kountouris, et al., 2014), the data of which, published internationally on the genetics, clinical trials and epidemiology of haemoglobinopathies, are regularly archived by an expert curator groups ${ }^{3}$; and CTGA database (Tadmouri, Al Ali, Al Haj Ali and Al Khaja, 2006), the genetic, clinical and epidemiological data of which concern the Arab world more specifically. These data were cross-referenced and checked with data from journal articles (Al-Gazali, Hamamy and Al-Arrayad, 2006; Alwan and Modell, 2003; Modell and Darlison, 2008). Missing data (incidence rates unavailable for some countries) were supplemented through the assumption of equivalent epidemiological rates with the closest countries on the same coast. The demographic data (population, crude birth rates) come from the latest forecasts of the United Nations Population Division (United Nations, 2019). To annualize all these data, the crude birth rates, initially provided per five-year period, were smoothed in a linear manner to obtain the most regular variations possible.

For each country, an epidemiological parameter and an estimated margin of error for the parameter were determined on the basis of previous data (number of new cases, average population size exposed):

3 The IthaGenes haemoglobinopathology collection method is uniform and systematic for all countries. 
- the incidence rate at birth on an annual basis, equal to the ratio of diseased newborns to the total newborns in a given year:

$$
T I=\frac{N m}{N}
$$

- the $95 \%$ confidence interval of the incidence rate at birth:

$$
\text { IC } 95 \%=[T I-1,96 \times S D ; T I+1,96 \times S D] \text { where } S D=\sqrt{\frac{N m}{N^{2}}}
$$

For each country, a projection of the sub-population of diseased newborns was derived from the average variant of the United Nations forecast. The process consisted in applying, for each year, the incidence rate at birth of 2020 to the annual number of births forecast by the United Nations through 2050:

$$
N m_{a}=T I_{2020} \times N_{a} \quad \forall a \in[2020 ; 2050]
$$

The forecasts thus established for each country can be used to estimate the proportion of diseased newborns out of the total number of births, taking account solely of the demographic trends likely to occur through to the end of the period under review.

For reasons of statistical significance, the comparisons concerned the country groups (European, Asian and African coasts) and their incidence rates at birth with 95\% confidence intervals in 2020 and 2050.

\section{Results}

\subsection{A review of $\beta$-thalassemia in the Mediterranean in 2020.}

In 2020, the population of the 21 Mediterranean countries under consideration in this paper was 522 million. The African coast is the most populous, accounting for $38.7 \%$ of the total, followed by the European coast (37.6\%) and Asian coast (23.7\%).

The number of $\beta$-thalassemia heterozygous individuals, i.e. those at risk of giving birth to diseased homozygous individuals, is 17.1 million, for a carrier prevalence of $3.3 \%$. For the entire geographic region under review, prevalence is distributed according to a gradient (Figure 1), where the proportion of carriers is 3.0\% on the European coast (the highest being in Albania (5.0\%), Italy (6.0\%) and Greece $(8.1 \%)), 3.2 \%$ on the Asian coast (the highest rates being in Syria (5.0\%), Israel (6.0\%) and Cyprus (a full $12.0 \%)$ ), and $3.6 \%$ on the African coast (the highest proportion being observed in Egypt, at 5.3\%).

Figure 1. Prevalence of $\beta$-thalassemia carriers in the countries on the Mediterranean coast, in 2020 (\%)

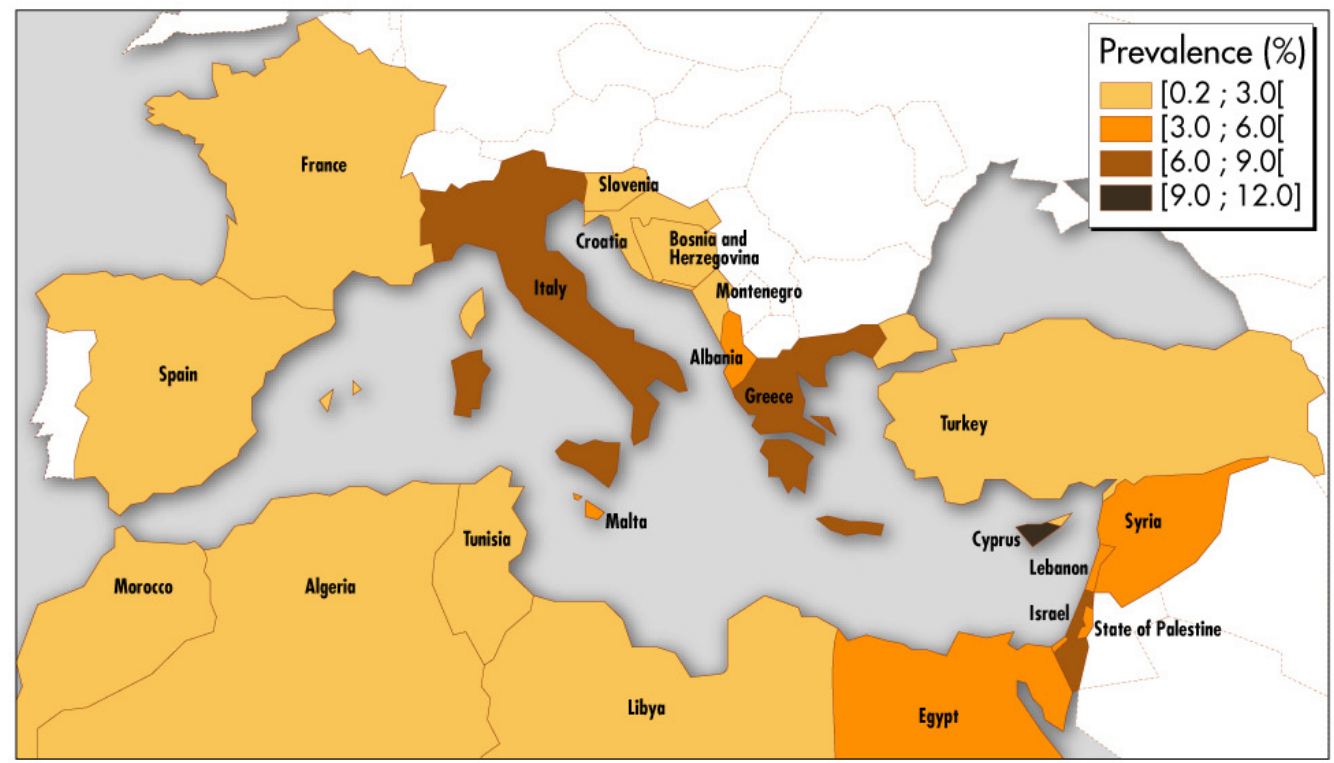

Own elaboration 
Overall, the $\beta$-thalassemia incidence rate at birth for Mediterranean countries is 31.0 per 100,000 newborns. But the epidemiological data, along with the distribution of health services and surveillance instruments, vary considerably from one country to the next (Table 1 and Figure 2).

On the European coast, the incidence rate at birth is 15.9 per 100,000, ranging from 1.4 in France to 56.9 in Albania. Five of the ten countries on the Northern coast are relatively well equipped in terms of $\beta$-thalassemia infrastructure: Spain (which lacks special medical centres or prevention programmes but where the incidence rate is just 1.6), France, Italy (an incidence rate of 52.0 and a targeted prevention programme at the regional level in Sardinia), Malta (no blood transfusions or iron chelators despite an incidence rate of 23.3) and Greece. Besides Greece, the countries on the Northern coast lacking special infrastructure are in the Balkans region.

The incidence rate at birth on the Asian coast (31.4 per 100,000 newborns) is nearly twice as high as on the European coast, varying from 3.0 in Israel to 458.3 in Cyprus. The six countries on the Eastern coast have prevention programmes, all of them national excluding the State of Palestine, which has a regional programme in the Gaza Strip. Israel and Cyprus are the only countries with special medical centres, blood transfusions and iron chelators, as well as national patient registers. The healthcare offering and epidemiological surveillance instruments are less substantial in Turkey, Lebanon, Syria and, above all, the State of Palestine, where the incidence rate is 42.5 per 100,000.

The African coast is the most affected, with an incidence rate at birth of 36.8 per 100,000. The Southern coast is also the least well equipped in infrastructure terms. Egypt (with an incidence rate of 58.9) has special medical centres at regional level together with a prevention programme, and Morocco (incidence rate of 8.0) has regional medical centres and blood transfusions and iron chelators at national level, but Libya, Tunisia and Algeria do not have $\beta$-thalassemia infrastructure.

Table 1. $\beta$-thalassemia incidence rate at birth and special infrastructure in the countries on the Mediterranean coast, in 2020

\begin{tabular}{|c|c|c|c|c|c|}
\hline Country & $\begin{array}{c}\text { Incidence } \\
\text { rate at birth } \\
\text { (per } 100,000)\end{array}$ & $\begin{array}{l}\text { Special medical } \\
\text { centres }\end{array}$ & $\begin{array}{c}\text { Availability } \\
\text { of blood } \\
\text { transfusions and } \\
\text { iron chelators }\end{array}$ & Patient registers & $\begin{array}{l}\text { Prevention } \\
\text { programmes }\end{array}$ \\
\hline Spain & 1.6 & - & National & National & - \\
\hline France & 1.4 & National & National & National & National \\
\hline Italy & 52.0 & National & National & National & Regional \\
\hline Malta & 23.3 & National & - & National & National \\
\hline Slovenia & $5.4 *$ & - & - & - & - \\
\hline Croatia & 2.9 & - & - & - & - \\
\hline $\begin{array}{l}\text { Bosnia and } \\
\text { Herzegovina }\end{array}$ & 4.1 & - & - & - & - \\
\hline Montenegro & $14.1 *$ & - & - & - & - \\
\hline Albania & 56.9 & - & - & - & - \\
\hline Greece & 13.9 & National & National & National & National \\
\hline Turkey & 13.8 & - & National & National & National \\
\hline Cyprus & 458.3 & National & National & National & National \\
\hline Syria & 90.7 & National & - & - & National \\
\hline Lebanon & 16.9 & National & National & - & National \\
\hline Israel & 3.0 & National & National & National & National \\
\hline State of Palestine & 42.5 & - & - & - & Regional \\
\hline Egypt & 58.9 & Regional & - & - & National \\
\hline Libya & 7.8 & - & - & - & - \\
\hline Tunisia & 11.0 & - & - & - & - \\
\hline Algeria & 6.8 & - & - & - & - \\
\hline Morocco & 8.0 & Regional & National & - & - \\
\hline
\end{tabular}

* The annual number of new cases for Slovenia and Montenegro (missing incidence data) was determined as 1 , the same as in Croatia and Bosnia and Herzegovina. 
Figure 2. Incidence rate at birth of $\beta$-thalassemia in the countries on the Mediterranean coast, in 2020 (per 100,000)

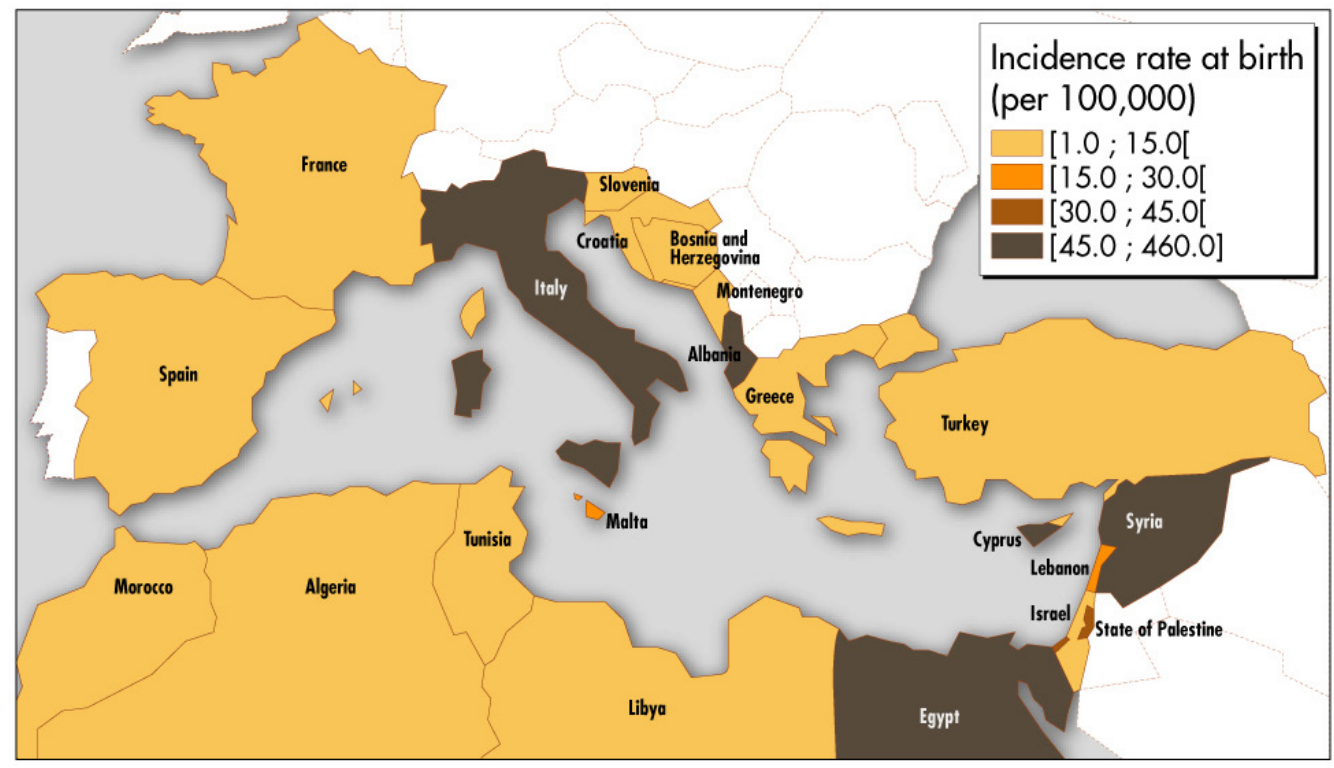

Own elaboration

\section{2. $\beta$-thalassemia in the Mediterranean in 2050. Population outlook}

According to the average variants of the United Nations forecasts, the number of newborns affected each year by $\beta$-thalassemia in the countries of the Mediterranean Basin will increase from 2,479 in 2020 to 2,899 in 2050 , for annual average growth of $0.5 \%$ over 30 years. The three coasts will contribute differently to this trend (Figure 3).

Figure 3. Trend in the number of newborns affected by $\beta$-thalassemia from 2020 to 2050 in the Mediterranean Basin

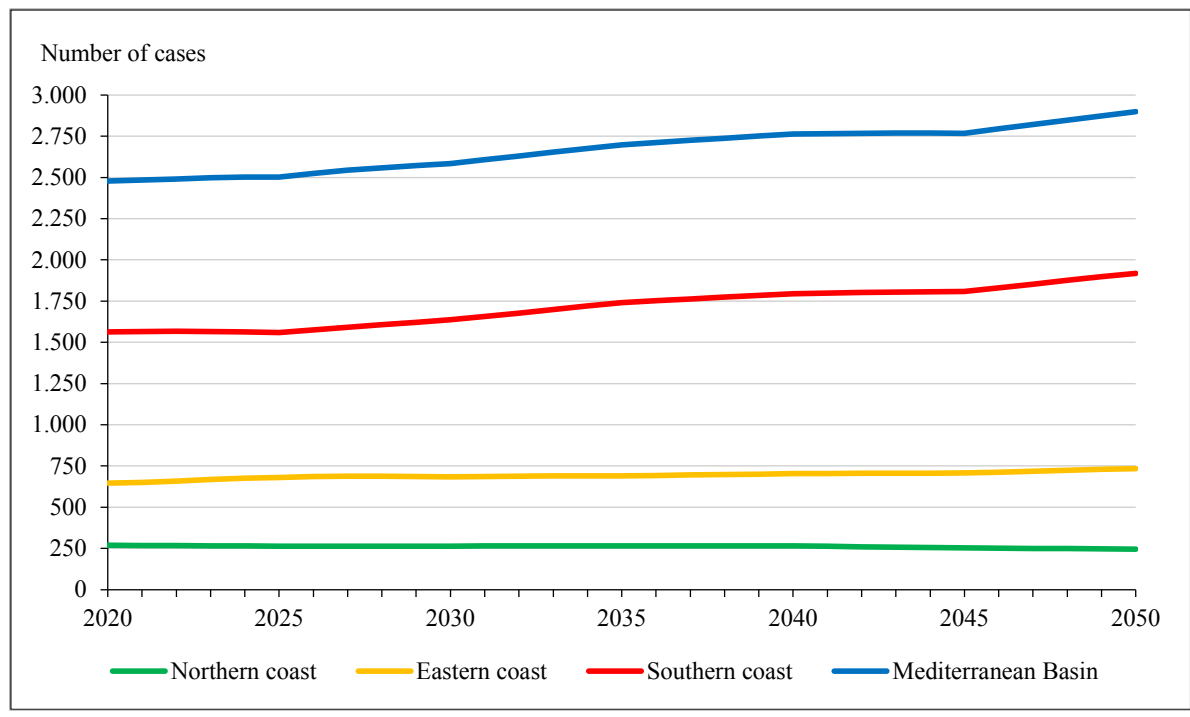

Own elaboration

The countries on the European coast have the lowest level of cases, from 269 diseased newborns in 2020 to an expected 246 in 2050, for negative annual average growth of $-0.3 \%$. The headcount mainly results from Italy, with 220 new cases in 2020 (81.8\% of Northern coast cases) and 206 new cases in 2050 $(83.7 \%)$.

The countries on the Asian coast have an intermediate level, with the number of new $\beta$-thalassemia cases expected to increase from 646 in 2020 to 734 in 2050, for annual average growth of $0.4 \%$. The 
largest proportion of new cases is in Syria, totaling 338 in 2020 (52.3\% of Asian coast cases) and expected to increase to 445 in 2050 (60.6\%).

The countries on the African coast have the highest level of cases, with the number of affected newborns expected to rise from 1,564 in 2020 to 1,919 in 2050, for average annual growth of $0.7 \%$. Egypt accounts for almost all of the new cases, from 1,423 diseased newborns in 2020 (91.0\% of Southern coast cases) to an expected 1,781 new cases in 2050 (92.8\%).

Figure 4 shows the trend in incidence rates at birth with 95\% confidence intervals in 2020 and 2050 for the three coasts.

For the European coast, the rate is expected to fall from 15.9 [14.0; 17.8] per 100,000 in 2020 to 15.4 [13.5; 17.3] 30 years later, the slight decrease being non-significant as demonstrated by the confidence intervals.

Incidence rates at birth are considerably higher on the Eastern and Southern coasts $(\mathrm{p}<0.05)$ and are expected to trend substantially upwards in the future. From 31.4 [29.0; 33.8] per 100,000 in 2020, the rate is expected to reach 36.2 [33.6; 38.9] in 2050. Incidence rates on the African coast are predicted to rise from 36.8 [35.0; 38.7] per 100,000 to 39.8 [38.0; 41.6] between 2020 and 2050. It should be noted that the differences estimated for the rates of the Eastern and Southern coasts between 2020 and 2050 are at the limit of statistical significance.

Figure 4. $\beta$-thalassemia incidence rates at birth in 2020 and 2050 in the Mediterranean Basin (per 100,000)

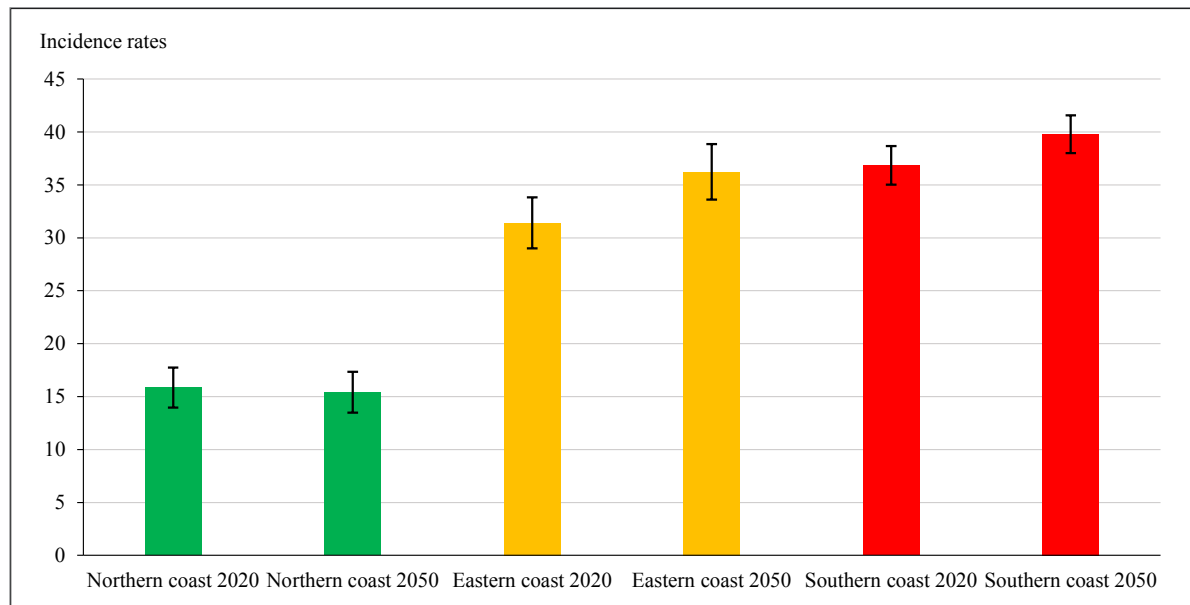

Own elaboration

\section{Discussion}

The $\beta$-thalassemia incidence rate is highly contrasted between different Mediterranean countries and regions. The European coast is the least impacted, with an incidence rate at birth of 15.9 per 100,000 newborns, and five out of the ten constituent countries have consequential health infrastructures. By 2050, the number of diseased newborns could decrease slightly, by $0.3 \%$ a year, for an incidence rate of 15.4 per 100,000. The incidence rate at birth in the six countries on the Asian coast is nearly twice as high, at 31.4 per 100,000 . These countries are characterized primarily by the existence of prevention programmes. In the next 30 years, the number of new cases at birth could increase in this region, by $0.4 \%$ a year, for an incidence rate of 36.2 per 100,000. The five countries on the African coast are more affected (with an incidence rate of 36.8 per 100,000) and less equipped in terms of special infrastructure. In addition, the incidence rate at birth in this region is expected to increase the most between 2020 and 2050, by $0.7 \%$ a year, for an incidence rate of 39.8 per 100,000. These results suggest that, failing adapted prevention measures, the health authorities could be faced with an increasing number of individuals with $\beta$-thalassemia.

While large-scale demographic forecasts are common, those on sub-populations of diseased individuals are rare. To our knowledge, this study is the first attempt to estimate a future number of newborns with $\beta$-thalassemia in the countries of the Mediterranean Basin. The review and long-term outlook proposed in this paper could help decision-makers relative to future needs for health and education services (Al- 
Sabbah, et al., 2017). Given the health equipment, economic resources and specialized staff resources of the countries, future trends can be drawn on when deciding between curative measures and preventive approaches in health policies and programmes. The relative insufficiency in the healthcare offering and the growing weight of the disorder have led Egypt, for example, to implement a strategy combining genetic advice, prenatal diagnoses, and voluntary pregnancy terminations. To gain the approval of the population, this prevention programme is accompanied by medical and religious considerations as part of in-depth discussions with couples at risk of having children with $\beta$-thalassemia (El-Beshlawy, et al., 2012).

The average variant of the UN projections, from which the outlook for diseased newborns was derived, demonstrates a few notable characteristics in the Mediterranean countries. The European coast has completed its demographic transition. The average number of children per woman, which in 2015-2020 stood at 1.9 in France (which currently has the highest fertility rate) and as low as 1.3 in Spain, Italy, Bosnia and Herzegovina, and Greece, is expected to remain at these levels between now and 2050. The natural growth rate (equal to the difference between the gross birth and death rates) was low in 2020 and could become negative by 2050 in all the countries on the Northern coast (from $-1.3 \%$ in France to $-7.2 \%$ in Croatia). The situation is different on the Eastern and Southern coasts, which have yet to complete their demographic transitions. On the Asian coast, the total fertility rate, ranging today from 1.3 children per woman (in Cyprus) to 3.4 (in the State of Palestine), is expected to trend downwards between now and 2050, with rates for the same two countries of between 1.5 and 2.5. Despite this decrease in fertility, the natural growth rate on the Eastern coast will remain high, trending in the State of Palestine, for example, from $23.7 \%$ o to $14.6 \%$ between $2015-2020$ and 2045-2050. The demographic situation is similar on the African coast. The average number of children per woman, ranging in 2015-2020 from 2.1 (in Tunisia) to 3.3 (in Egypt), could stand at between 1.9 and 2.5 by 2050. But the natural growth rate on the Southern coast could remain high, in Egypt decreasing from 17.9\%o in 2015-2020 to $12.6 \%$ in 2045-2050.

$\beta$-thalassemia incidence rates at birth, based on the birth rates in the countries on the Mediterranean coast, are influenced by the trend in fertility ${ }^{4}$ as well as the age pyramid of the population and, in particular, the number of women of child-bearing age. Barring a gradual, though unlikely, change in the headcount of this population category, the incidence rate at birth could be influenced by the widespread implementation of antinatal practices against the disease. As things stand, uncertainty over the epidemiological data was corrected in this study, both for 2020 and 2050, by $95 \%$ confidence intervals on incidence rates. A more precise approach would have consisted in having exhaustive patient registers for each country. This would help to measure the intensity of inflows (new diseased individuals by age, reappearance of missing individuals in monitoring) and outflows (deaths by age, missing individuals in monitoring) contributing to the predictable trend in the number of diseased individuals year after year, as is the case for cystic fibrosis in Europe between 2010 and 2025 (Burgel, et al., 2015).

The heterogeneity observed in special infrastructure (special medical centres, availability of blood transfusions and iron chelators, prevention programmes) results from several factors, at least two of which may be mentioned here:

- the economic situation of the countries, which is extremely uneven. In 2019, gross national product per inhabitant averaged USD 33,400 for the countries on the European coast, USD 31,100 for those on the Asian coast (excluding the State of Palestine, for which data are not available), and USD 11,640 for those on the African coast (The World Bank, 2019);

- the major crises, such as conflicts and wars, having occurred in the Balkans and which could weigh on health policies on a lasting basis.

\section{Conclusions}

An overview of $\beta$-thalassemia epidemiology and currently available medical resources, as well as data on the potential trend in affected children in the coming decades, could help to mobilize the countries

\footnotetext{
4 With a lower fertility rate (low UN variant), the effect of which would be seen in the number of women at child-bearing age and in the number of births, $\beta$-thalassemia incidence rates at birth would be lower; with a higher fertility rate (high variant), incidence rates would, for opposing reasons, be higher.
} 
concerned as regards healthcare initiatives and strategies. Depending on the national situation, these actions could address forecasts on the allocation of resources, the development of medical centres and surveillance systems, and the implementation of prevention programmes. At supranational level, transfers of knowledge and biomedical techniques for prenatal diagnoses could also be envisioned.

The analysis carried out for $\beta$-thalassemia on the diversity of peoples living on the Mediterranean coast must not be isolated. To the benefit of public health, the same approach could be implemented for other genetic hemoglobin diseases (for example, sickle cell anemia in Africa, the Middle East and India), since these monogenic diseases are the most widespread in the world, the number of heterozygous carriers accounting for a full $7 \%$ of the world population.

\section{References}

Al-Gazali, L., Hamamy, H., \& Al-Arrayad, S. (2006). Genetic disorders in the Arab world. British Medical Journal, 333, 831-834. https://doi.org/10.1136/bmj.38982.704931.AE

Al-Sabbah, H., Khan, S., Hamadna, A., Abu Ghazaleh, L., Dudin, A. , \& Karmi, B.A. (2017). Factors associated with continuing emergence of $\beta$-thalassemia major despite prenatal testing: a crosssectional survey. International Journal of Women's Health, 9, 673-679. https://doi.org/10.2147/IJWH. $\underline{S 141936}$

Allison, A.C. (2009). Genetic control of resistance to human malaria. Current Opinion in Immunology, 21(5), 499-505. https://doi.org/10.1016/j.coi.2009.04.001

Alwan, A., \& Modell, B. (2003). Recommendations for introducing genetics services in developing countries. Nature Reviews Genetics, 4, 61-68. https://doi.org/10.1038/nrg978

Angastiniotis, M., \& Lobitz, S. (2019). Thalassemias: an overview. International Journal of Neonatal Screening, 5(16). https://doi.org/10.3390/ijns5010016

Bener, A., \& Mohammad, R.R. (2017). Global distribution of consanguinity and their impact on complex diseases: Genetic disorders from an endogamous population. The Egyptian Journal of Medical Human Genetics, 18, 315-320. https://doi.org/10.1016/j.ejmhg.2017.01.002

Bittles, A.H., Mason, W.M., Greene, J., \& Rao, N.A. (1991). Reproductive behavior and health in consanguineous marriages. Science, 252(5007), 789-794. https://doi.org/10.1126/science.2028254

Burgel, P.R., Bellis, G., Olesen, H.V., Viviani, L., Zolin, A., Blasi, F., \& Elborn, J.S. (2015). Future trends in cystic fibrosis demography in 34 European countries. European Respiratory Journal, 46, 133-141. https://doi.org/10.1183/09031936.00196314

Cao, A., \& Galanello, R. (2010). Beta-thalassemia. Genetics in Medicine, 12(2), 61-76. https://doi. org/10.1097/GIM.0b013e3181cd68ed

Cao, A., Rosatelli, M.C., Monni, G., \& Galanello, R. (2002). Screening for thalassemia: a model of success. Obstetrics and Gynecology Clinics of North America, 29(2), 305-328. https://doi.org/10.1016/S0889$\underline{8545(01) 00006-7}$

Ceci, A., Baiardi, P., Catapano, M., Felisi, M., Cianciulli, P., De Sanctis, V., ..., \& Maggio, A. (2006). Risk factors for death in patients with $\beta$-thalassemia major: results of a case-control study. Haematologica, 91, 1420-1421.

De Sanctis, V., Kattamis, C., Canatan, D., Soliman, A.T., Elsedfy, H., Karimi, M., ..., \& Angastiniotis, M. (2017). $\beta$-thalassemia distribution in the old world: an ancient disease seen from a historical standpoint. Mediterranean Journal of Hematology and Infectious Diseases, 9(1). http://dx.doi. org/10.4084/MJHID.2017.018

El-Beshlawy, A., El-Shekha, A., Momtaz, M., Said, F, Hamdy, M., Osman, O., ..., \& Petrou, M. (2012). Prenatal diagnosis for thalassaemia in Egypt: what changed parents' attitude? Prenatal Diagnosis, 32(8), 777-782. https://doi.org/10.1002/pd.3901

Flint, J., Harding, R.M., Boyce, A.J., \& Clegg, J.B. (1998). The population genetics of the haemoglobinopathies. Bailliere's Clinical Haematology, 11(1), 1-51. https://doi.org/10.1016/S0950$\underline{3536(98) 80069-3}$ 
Galanello, R., \& Origa, R. (2010). Beta-thalassemia. Orphanet Journal of Rare Diseases, 5(11). https://doi. org/10.1186/1750-1172-5-11

Godard, B., Kate, L.T., Evers-Kiebooms, G., \& Aymé, S. (2003). Population genetic screening programmes: principles, techniques, pratices and policies. European Journal of Human Genetics, 11, p. S49-S87. https://doi.org/10.1038/sj.ejhg.5201113

Higgs, D.R., Engel, J.D., \& Stamatoyannopoulos, G. (2012). Thalassaemia. The Lancet, 379, 373-383. https://doi.org/10.1016/S0140-6736(11)60283-3

Karnon, J., Zeuner, D., Brown, J., Ades, A.E., Wonke, B., \& Modell, B. (1999). Lifetime treatment costs of $\beta$-thalassaemia major. Clinical and Laboratory Haematology, 21(6), 377-385. https://doi.org/10.1046/ j.1365-2257.1999.00262.x

Kountouris, P., Lederer, C.W., Fanis, P., Feleki, X., Old, J., \& Kleanthous, M. (2014). IthaGenes: an interactive database for haemoglobin variations and epidemiology. PLoS ONE, 9(7): e103020. https:// doi.org/10.1371/journal.pone.0103020

Modell, B., \& Darlison, M. (2008). Global epidemiology of haemoglobin disorders and derived service indicators. Bulletin of the World Health Organization, 86(6), 480-487. https://doi.org/10.2471/ BLT.06.036673

Tadmouri, G.O., Al Ali, M.T., Al Haj Ali, S., \& Al Khaja, N. (2006). CTGA: the database for genetic disorders in Arab populations. Nucleic Acids Research, 34, Database issue, D602-D606. https://doi. org/10.1093/nar/gkj015

Tadmouri, G.O., Nair, P., Obeid, T., Al Ali, M.T., Al Khaja, N., \& Hamamy, H.A. (2009). Consanguinity and reproductive health among Arabs. Reproductive Health, 6. https://doi.org/10.1186/1742-4755-6$\underline{17}$

The World Bank (2019). GNI per capita, PPP (current international \$). Retrieved from http://data. worldbank.org/indicator/NY.GNP

United Nations (2019). World Population Prospects: the 2019 revision. Retrieved from https://population. un.org/wpp/

Weatherall, D.J., \& Clegg, J.B. (2001). Inherited haemoglobin disorders: an increasing global health problem. Bulletin of the World Health Organization, 79(8), 704-712.

World Health Organization (WHO) (2005). Lutte contre les maladies génétiques. Rapport du Conseil Exécutif, EB116/3, 1-5. 